\title{
Co-Movement, Dependence Structure and Ethical Investment Funds under GFC
}

\author{
Robin Hang Luo', M. Ishaq Bhatti ${ }^{2 *}$ \\ ${ }^{1}$ School of Economics, Xihua University, Sichuan, China \\ ${ }^{2}$ Department of Economics and Finance, La Trobe Business School, La Trobe University, Melbourne, Australia \\ Email: robin.h.luo@gmail.com, ${ }^{\star}$ i.bhatti@latrobe.edu.au
}

How to cite this paper: Luo, R.H. and Bhatti, M.I. (2019) Co-Movement, Dependence Structure and Ethical Investment Funds under GFC. Theoretical Economics Letters, 9, 1852-1872. https://doi.org/10.4236/tel.2019.96118

Received: April 12, 2019

Accepted: August 11, 2019

Published: August 14, 2019

Copyright (c) 2019 by author(s) and Scientific Research Publishing Inc. This work is licensed under the Creative Commons Attribution International License (CC BY 4.0).

http://creativecommons.org/licenses/by/4.0/

(c) (i) Open Access

\begin{abstract}
This paper extends the recent work of Mansor et al. [1] who use panel regression to measure ethics based Islamic mutual fund performance and note the various methodological issues in this respect. We attempt to capture the co-movement and dependence structure of the fund index with five major equity indices before and during the Global financial crises (GFC). Four models-CAPM, normal Copula, symmetrised Joe-Clayton Copula and Rotated Gumbel Copula-are used to analyse the co-movement and dependence structure of Islamic investment funds. Our findings show that the ethical investment funds have low dependence with the major market indices. The fluctuations in the financial markets in the U.S., the U.K., Germany and Japan are less likely to affect the Islamic investment funds than other financial assets. However, the time-varying dependence increases dramatically during the GFC indicating that the diversification merits of Islamic equity funds in the portfolio deteriorate in the bear market. Some of the empirical results drawn in this paper will raise awareness among both academicians and financiers about the importance of Islamic investment funds during and out of crises periods.
\end{abstract}

\section{Keywords}

Co-Movement, Dependence Structure, Ethical Investment, Islamic Mutual Funds, Copula, EVT

\section{Introduction}

The last three decades have seen tremendous interest and growth in the field of ethical investment. For example, there are 1204 ethical retail investment funds in Europe with total size of about 136 billion Euros, with average annual growth rate of 7\% [2]. UK's ethical fund "Friends Provident Stewardship Fund" is even 
growing faster than the overall European. Though the effect of post Brexit is unknown, Latest figures show that in the USA ethical investment is over 20 times than that of the UK. Companies which are engaged in tobacco, armaments and other typically unethical investment activities are excluded by US ethical fund managers. Islamic investment fund (IMF) or Islamic Mutual fund may be more concerned with a very different set of ethical criteria from Western "green" or ethical investors, but the issues of business ethics, stock selection and screening technique are of common interest to general ethical investment and the IMF which is based on interest free settings due to religious ethics, as interest is prohibited in Islamic banking and finance (IBF) products, including IMF.

Islamic banking and finance industry is growing faster than both ethical and/or conventional banking and finance. There are more than 600 Islamic financial institutions now operate in 75 countries with an average annual growth of 15 percent and the total global size of the Islamic financial assets standing at US \$1.6 trillion [3]. Takaful, Sukuks, and Islamic equity funds are the fastest growing segments of Islamic banking and finance [4] [5]. In the early 1990s, there were less than 10 Shariah-complaint funds in the world, mainly in the Middle East. The number was close to 400 in 2009 [6]. Over the years, the number of Islamic investment funds has grown and eventually trickled across the globe. Increasing numbers of Western financial institutions are now involved in Islamic investment funds to attract Muslim customers worldwide. The amount of finance designated as being ethically invested in the UK currently exceeds $£ 1$ billion, of which over $£ 414$ million is in the Friends Provident Stewardship Fund. In the USA over 20 times this amount is invested ethically, including finance which is invested in environmentally friendly projects and companies which are screened using moral criteria. Companies which are engaged in tobacco production or distribution or are involved in armaments are typically excluded by US ethical fund managers. Islamic investors may be concerned with a very different set of ethical criteria from Western "green" or ethical investors, but the issues of stock selection and screening technique are of mutual interest. There is arguably much that both parties can learn from one another, especially with respect to investment techniques, even though the underlying moral value systems are very different, and there is no question of importing or exporting cultural norms or religious beliefs.

The rapid growth of Islamic investment funds raises a series of important questions: Is the growth in Islamic investment funds a result of the comparative advantages of the Islamic fund paradigm or is it largely attributable to the worldwide Islamic resurgence since the late 1960s? Do Islamic investment funds provide greater positive returns compared to the Islamic market index and the major Western market indices? And did these returns move together before and during a crisis such as the Asian and global financial crises?

The growing Islamic finance literature has attempted to answer the above questions and a few have documented that the performance of Islamic invest- 
ment funds may be different relative to the conventional market benchmark due to the fact that Shari ah prohibits any involvement in interest-based assets such as conventional bonds, speculative investment such as derivatives, and specific prohibited industries [7] [8] [9] [10] [11]. The specific guidelines followed by Islamic investment funds stem from the main Shari ah sources-the Quran, the Hadith and Ijtihad [9] [12] [13] [14]. The Quran is the primary source of Islam - the words of God as revealed to the Prophet Mohammed, peace are upon him (PBUH). The Hadith consists of the narrated records of the actions and sayings of the Prophet himself. Ijtihad is derived from Shari ah laws. Qualified scholars interpret these sources and specify Shariah-compliance strategies to be followed within each asset class selection of investment portfolios. However, Chong and Liu [15] argue that the rapid growth in Islamic banking and finance is largely driven by the Islamic resurgence worldwide rather than by the advantages of the profit-and-loss sharing (PLS) paradigm. They compare the Islamic investment rates and conventional deposit rates collected from the Monthly Statistical Bulletin published by the Bank Negara Malaysia (central bank of Malaysia) and find that the Islamic deposits are not interest-free and are closely pegged to the conventional deposits.

Previous research has also reported some evidence on the risk and return characteristics of Islamic funds using fund level data. For instance, Abdullah et al. [16] analyse 65 Malaysian unit trusts including 14 Islamic and 51 conventional funds and conclude that both types of funds slightly underperformed the Kuala Lumpur Composite Index (KLCI) benchmark [17]. After taking risk into account, they find that Islamic mutual funds (IMFs) perform better than the conventional funds (CMFs) during the bear market, but underperform during the bull market. Hayat and Kraeussl [8] expand the sample to 145 Islamic equity funds (IEFs) and analyse the risk-return characteristics in a more rigorous manner. They argue that IEFs are underperformers compared to Islamic, as well as, to the conventional equity benchmarks, and the underperformance seems to have increased during the GFC. Hoepner et al. [18] analyse the financial performance and investment style in IMFs employing a bigger sample including 265 IEFs from 20 countries. They find that the performance of IMFs from countries with more developed Islamic financial markets is comparable to international equity benchmarks, while funds from countries with less Islamic assets, especially Western nations, tend to significantly underperform. Mansor et al. [1] follow Hayat and Kraeussl's [8] approach to measure the impact of fees on selectivity and timing for the Malaysian IMFs using panel data regression models. They observe that the fund managers lack the expertise with respect to the choice of fund selection and timing. However, they also note that the IMFs perform marginally better than the conventional funds. Lastly, their findings regarding human capital in IMFs are in line with those partially observed by Basov and Bhatti [9] who use a Mechanism approach.

Most of the studies mentioned above use the CAPM model [1] [8] [18] and 
the Carhart model [18], with the exception of Basov and Bhatti [9] to examine the financial performance of Islamic funds. However, such a setting has two limitations. First, it is empirically proven that asset returns from a wide range of markets are leptokurtic, being heavy-tailed and overly concentrated around the mean when compared to a Gaussian distribution [19]. This means that when the return distribution deviates from the elliptic class of distributions, including Gaussian, a single statistic such as the systematic risk measure (beta) estimated by Hayat and Kraeussl [8] or Mansor et al. [1] is unable to correctly assess the dependency structure between the returns. Tail dependence may also differ from dependence close to the mean [20] [21] [22]. Further, the dependence between two asset returns as the market rises may be different than the dependence as the market falls. Shaw [23] has pointed out that the linear correlation coefficient cannot capture the non-linear dependence relationships that exist between many financial series. Second, correlation coefficient estimated using CAPM or Carhart model is simply a scalar measure of dependency and it cannot embody everything one would like to know about the dependence structure. It is therefore not an appropriate dependence measure for very heavy-tailed distributions [24].

Our study contributes to the literature by providing empirical evidence of the co-movement and dependence structure of Islamic investment funds with the Islamic and the Western stock indices employing both the linear (CAPM) and non-linear (Copula) methods. Dependence structure is an important issue in measuring the co-movement of financial indices. As mentioned above, linear correlation, though it provides an easy and convenient way to describe co-movement between two random variables, is not an appropriate dependence measure and maybe highly biased in certain non-normal situations. In addition, asymmetric dependence in equity markets and foreign exchange markets is also documented in recent literature including Longin and Solnik [25], Ang and Chen [26], Patton [27], Rodriguez [28], Ahsanullah and Bhatti [29], Bhatti and Nguyen [20] and Nguyen et al. [21] [22], among others. These features can be easily captured in Copula models with tail dependence parameters. Therefore, the Copula is a more powerful and attractive tool to analyse the dependence between margins since it does not require the assumption of normality in the marginal distributions [29].

Our empirical results indicate some interesting findings. Firstly, the four normality tests indicate that the returns for the Europe Open-end Islamic Shari ah Equity index and the five major stock indices are leptokurtic. All normality tests reject the null hypothesis of Gaussian distributed returns. Secondly, the CAPM regression results imply that Islamic equity funds provide better diversification benefits to the investors, even when compared to the Islamic market index. Thirdly, normal Copula parameter estimates suggest that the Islamic investment funds have low dependence with the major Western market indices. Lastly, the time-varying dependence between Islamic Shariah Equity index and Dow Jones Islamic Market index, and the four major Western market indices in- 
creases dramatically during the GFC. The diversification benefits of including Islamic equity funds in the portfolio seem to deteriorate in a financial crisis.

The rest of the paper is organised as follows. Section 2 provides a description of Islamic investment funds' characteristics and categories. Section 3 presents the research methodologies including the CAPM and the various Copulas namely the normal Copula, the symmetrised Joe-Clayton (SJC) Copula and the Rotated Gumbel Copula, to analyse the co-movement and dependence structure of Islamic investment fund index and the five major stock indices. The empirical results are presented in Section 4 including a detailed discussion. The final section concludes.

\section{The Islamic Investment Fund: Characteristics and Categories}

The term Islamic Investment Fund is defined by Usmani [30] as "a joint pool wherein the investors contribute their surplus money for the purpose of its investment to earn halal profits in strict conformity with the precepts of Islamic Shariah". The subscribers of the fund may receive a certificate of subscription which entitles them to receive pro-rata profits accruing to the fund. These certificates are subject to two sets of guidelines; sectoral guidelines and financial guidelines [31].

First, Shari ah clearly defines business and financial activities that are prohibited for Muslims including consumption of alcohol, pork products, gambling, and porn industries. Further, the terms agreed upon must conform to the Islamic principles. This is called Shari ah compliancy.

Second, instead of a fixed return that is tied up to their face value, these certificates must carry a pro-rata profit actually earned by the fund. Therefore, neither the principal nor the rate of profit (tied up with the principal) can be guaranteed. The subscribers must enter into the fund with a clear understanding that the return on their subscription is tied to the actual profits earned or losses suffered by the fund. If the fund earns profits, the returns in their subscription will increase to that proportion. Similarly, in case the fund suffers a loss, that will have to be shared also, unless the loss is caused by the negligence or mismanagement in which case the management, and not the fund, will be liable to compensate it.

\subsection{Islamic Equity Funds}

In an equity fund, the amounts are invested in the shares of joint stock companies. The profits are mainly achieved through capital gains; by purchasing the shares and selling them when their prices have increased. Profits can also be by way of dividends distributed by the relevant companies. Dealing in equity shares is acceptable in the Shariah subject to the following conditions; 1) The main business of the company is not in violation of the Shariah;2) If the main business of the companies is halal, but they deposit the surplus amounts in an interest-bearing account or borrow money on interest, the shareholder must express his disapproval against such dealings; 3) If some income from interest-bearing 
accounts is included in the income of the company, the proportion of such income must be less than $5 \%$ and it must be given in charity; and 4) The shares of a company are negotiable only if the company owns some non-liquid assets.

One of the major indices of Islamic investment funds is the Europe Open-end Islamic Shariah Equity index provided by Morningstar [32]. It consists of 15 Shari ah-compliant open-end funds. They are Al Dar World Equities Acc, Emirates Dynamic Liquid I Acc, Emirates Dynamic Liquid R Acc, Emirates Islamic Eq Trading Inst Acc, Emirates Islamic Eq Trading Sophist Acc, Emirates Islamic Global Balanced USD Acc, Emirates MENA Opps Daily Dirham AED Acc, Emirates MENA Opps Daily USD Acc, Emirates MENA Opps USD Acc, Emirates Real Estate Dirham AED Acc, Emirates Real Estate USD Acc, Emirates Real Estate USD Inc, HSBC Amanah Global Equity Index Fund Inc (GBP), SWIP Islamic Global Equity C Acc, and UBS (Lux) Islamic Fund Global Equity SICAV Acc. This paper attempts to investigate the co-movement and dependence structure of this Islamic Shari ah Equity index with the major Islamic and Western stock indices (see Sections 3 and 4).

\subsection{Islamic Hedge Funds}

Hedge fund is a private investment vehicle for high net worth and institutional investors. It is typically privately placed and not subject to the regulation of a public mutual fund. The Dubai Multi Commodities Centre Authority (DMCCA) and Shari ah Capital Inc announced the Dubai Shari ah Hedge Fund index on 7 January 2009 [33]. It is the first internationally recognised index comprising exclusively of Shariah complaint hedge funds. The index reflects the performance of the DSAM Kauthar Commodity Fund (DKCF); an equally-weighted fund-of-funds comprising initially of four single-strategies, commodity-focused funds that invest exclusively in Shari ah complaint long/short equity hedge funds on the Al Safi Trust platform. The Al Safi Trust is a comprehensive Shari ah complaint platform designed specifically for hedge funds and launched by Barclays Capital and Shari ah Capital. The four funds included in the Dubai Shari ah Hedge Fund Index are DSAM Kauthar Gold Fund (25\%), DSAM Kauthar Energy Fund (25\%), DSAM Kauthar Natural Resources Fund (25\%), and DSAM Kauthar Global Resources \& Mining Fund (25\%).

The launch of the Dubai Shariah Hedge Fund index provides a benchmark for investors in Shariah compliant hedge funds who are looking for absolute investment returns in commodities during the periods of market volatility.

\section{Model Specifications}

\subsection{CAPM Model}

We follow Hayat and Kraeussl [8] to investigate the risk and return characteristics of the Europe Open-end Islamic Shariah Equity and the major Western stock indices and the Islamic market index via standard CAPM regressions of weekly excess returns: 


$$
R_{i, t}-R_{f, t}=\alpha_{i}+\beta_{i}\left(R_{m, t}-R_{f, t}\right)+\mu_{i, t}
$$

where $R_{i, t}$ is the weekly return of Europe Open-end Islamic Shariah Equity index in percentage terms; $R_{f, t}$ is the weekly return of 3-month Treasury Bill secondary market rate, representing the risk free benchmark; $R_{m, t}$ is the weekly return of individual stock market index in percentage terms, including the Dow Jones Islamic Market index, Frankfurt Stock Exchange DAX index, the FTSE 100 index, the Nikkei 225 index, and the S \& P 500 index. $\alpha_{i}$ and $\beta_{i}$ are coefficients indicating outperformance and systematic risk, respectively, and $\mu_{i, t}$ is the error term. We follow the suggested procedure by Hayat and Kraeussl [8] and run five individual regressions with Newey-West heteroscedasticity and autocorrelation robust standard errors and obtain estimated alpha and beta coefficients.

\subsection{Copula Models}

As a dependency measure, the correlation coefficient estimated using CAPM contains a number of pitfalls as mentioned previously. Copula models, on the other hand, represent a way of trying to extract the dependence structure from the joint distribution and to extricate dependence and marginal behaviour. This allows for the decomposition of a joint distribution into its marginal distributions and its dependence function ${ }^{1}$, i.e., the Copula function [34]. We may construct the Copula function by transforming the random variables $Y_{1}$ and $Y_{2}$ with the joint distribution function $F\left(y_{1}, y_{2}\right)=\operatorname{Pr}\left(Y_{1} \leq y_{1}, Y_{2} \leq y_{2}\right)$ into their uniform marginal distributions (CDFs) denoted as $F_{1}$ and $F_{2}$, respectively.

$$
F\left(y_{1}, y_{2}\right)=\operatorname{Pr}\left(F_{1}\left(Y_{1}\right) \leq F_{1}\left(y_{1}\right), F_{2}\left(Y_{2}\right) \leq F_{2}\left(y_{2}\right)\right)=C\left(F_{1}\left(y_{1}\right), F_{2}\left(y_{2}\right)\right)
$$

Nelsen [34] and Patton [27] provide complete discussions on Copula and conditional Copula theory. We follow their methods for the normal (Gaussian) and Generalized Joe-Clayton (GJC) Copula. The former is a good model to measure general dependence and the latter is good at modeling both upper and lower tail dependencies. These two types of Copula models will give us a fuller picture of dependence structures for the indices.

Gaussian Copula has the dependence function associated with bivariate normality and can be expressed as:

$$
C^{N}(u, v ; \rho)=\int_{-\infty}^{\Phi^{-1}(u)} \int_{-\infty}^{\Phi^{-1}(v)} \frac{1}{2 \pi \sqrt{1-\rho^{2}}} \exp \left\{\frac{-\left(r^{2}-2 \rho r s+s^{2}\right)}{2\left(1-\rho^{2}\right)}\right\} \mathrm{d} r \mathrm{~d} s
$$

where $\Phi^{-1}$ is the inverse of the standard normal CDF, and $\rho$ is the general dependence parameter. We assume that the functional form of the Copula is fixed throughout the sample period while the dependence parameter is time-varying following some evolution equation. Following Patton [27] we assume the following evolution dynamics for $\rho_{t}$ :

${ }^{1}$ For recent review on this topic readers are referred to Bhatti M. I. \& Do, H. Q. (2019). Recent development in copula and its applications to the energy, forestry and environmental sciences. International Journal of Hydrogen Energy. 44:19453-19473. 


$$
\rho_{t}=\Lambda\left(\omega_{\rho}+\beta_{\rho} \times \rho_{t-1}+\alpha_{\rho} \times \frac{1}{p} \sum_{j=1}^{p}\left[\Phi^{-1}\left(u_{t-j}\right) \times \Phi^{-1}\left(v_{t-j}\right)\right]\right)
$$

where $\Lambda(x)=\frac{1-\mathrm{e}^{-x}}{1+\mathrm{e}^{-x}}$ is the modified logistic transformation, aiming to keep $\rho_{t}$ within the $(-1,1)$ interval. We assume that the Copula dependence parameter follows an ARMA $(1,10)$ type process ${ }^{2}$, in which the autoregressive term $\left(\beta_{\rho} \times \rho_{t-1}\right)$ captures the persistence effect and the last term

$\left(\alpha_{\rho} \times \frac{1}{10} \sum_{j=1}^{10}\left[\Phi^{-1}\left(u_{t-j}\right) \times \Phi^{-1}\left(v_{t-j}\right)\right]\right)$ captures the variation effect on independence.

The second Copula used in our study is the symmetrised Joe-Clayton (SJC) Copula that is a slight modification of the original Joe-Clayton Copula. Joe-Clayton Copula proposed by Joe [35] itself is a Laplace transformation of the Clayton's Copula. It is defined as:

$$
C^{J C}\left(u, v ; \tau^{U}, \tau^{L}\right)=1-\left(1-\left\{\left[1-(1-u)^{k}\right]^{-\gamma}+\left[1-(1-v)^{k}\right]^{-\gamma}-1\right\}^{-1 / \gamma}\right)^{1 / k}
$$

where $k=1 / \log _{2}\left(2-\tau^{U}\right), \quad \gamma=-1 / \log _{2}\left(\tau^{L}\right)$ and $\tau^{U} \in(0,1], \quad \tau^{L} \in(0,1]$.

Unlike the Gaussian Copula, there are two tail dependence parameters, $\tau^{U}$ and $\tau^{L}$, in this Copula function [20]. The upper tail dependence is defined as:

$$
\begin{aligned}
\tau^{U} & =\lim _{\varepsilon \rightarrow 1} \operatorname{Pr}[U>\varepsilon \mid V>\varepsilon]=\lim _{\varepsilon \rightarrow 1} \operatorname{Pr}[V>\varepsilon \mid U>\varepsilon] \\
& =\lim _{\varepsilon \rightarrow 1}(1-2 \varepsilon+C(\varepsilon, \varepsilon) /(1-\varepsilon))
\end{aligned}
$$

If this limit exists, the Copula shows upper tail dependence when $\tau^{U} \in(0,1]$ and no tail dependence when $\tau^{U}=0$. Similarly, we can define lower tail dependence as:

$$
\tau^{L}=\lim _{\varepsilon \rightarrow 0} \operatorname{Pr}[U \leq \varepsilon \mid V \leq \varepsilon]=\lim _{\varepsilon \rightarrow 0} \operatorname{Pr}[V \leq \varepsilon \mid U \leq \varepsilon]=\lim _{\varepsilon \rightarrow 0} C(\varepsilon, \varepsilon) / \varepsilon
$$

If this limit exists, the Copula shows lower tail dependence when $\tau^{L} \in(0,1]$ and no tail dependence when $\tau^{L}=0$. By construction, the Joe-Clayton Copula always gives asymmetric tail dependence even if the two tail dependence measures are in fact equal. In order to overcome this shortcoming we will use the SJC Copula proposed by Patton [27] in the present study, given by

$$
\begin{aligned}
& C^{S J C}\left(u, v ; \tau^{U}, \tau^{L}\right) \\
& =0.5 \times\left(C^{J C}\left(u, v ; \tau^{U}, \tau^{L}\right)+C^{J C}\left(1-u, 1-v ; \tau^{U}, \tau^{L}\right)+u+v-1\right)
\end{aligned}
$$

where $C^{J C}$ represents the Joe-Clayton Copula. The advantage of the SJC Copula is that it can be symmetric when $\tau^{U}=\tau^{L}$, whereas the original Joe-Clayton Copula still allows asymmetry even though tail dependence is actually symmetric. The property makes the SJC Copula more attractive for empirical work because of its generality.

${ }^{2}$ The dynamics of the tail dependence parameters are akin to a restricted ARMA $(1, q)$ process. Patton [27] uses a fixed value of $p=10$. In our study, however, we estimate the time-varying SJC Copula with a number of different values of $p$ up to $p=12$ and choose the best fitting model in terms of the likelihood. 


\section{Empirical Results}

\subsection{Data Description}

We examine the interaction between the Europe Open-end Islamic Shari ah Equity fund and the five major stock indices. These are labelled as, "ISE" for the Islamic Shari ah Equity index, "DJIM" for the Dow Jones Islamic Market index, "DAX" for the Frankfurt Stock Exchange DAX index, "FTS" for the FTSE 100, "NIK" for the Nikkei 225, and "S \& P" for the S \& P 500. Weekly returns are computed in percentage terms and are obtained from the Morningstar Direct 3.61 from January 5th, 1997 to April 11th, 2009. The sample consists of more than 12 years of weekly data covering 640 data points. Table 1 gives summary statistics on the returns of Europe Open-end Islamic Shari ah Equity index and all the other stock market indices.

Table 1. Summary statistics on weekly returns.

\begin{tabular}{|c|c|c|c|c|c|c|}
\hline & ISE & DJIM & DAX & FTS & NIK & $S \& P$ \\
\hline \multicolumn{7}{|c|}{ Panel A: Descriptive Statistics } \\
\hline Mean & 0.0149 & 0.0899 & 0.1349 & 0.0913 & -0.0685 & 0.0907 \\
\hline Std. Dev. & 2.8360 & 2.6514 & 3.5790 & 2.6386 & 3.1874 & 2.6953 \\
\hline Skewness & 0.1520 & -0.7273 & -0.3027 & -0.6140 & -0.7380 & -0.5015 \\
\hline Kurtosis & 14.823 & 9.0081 & 6.4929 & 11.463 & 8.6013 & 8.1367 \\
\hline \multicolumn{7}{|c|}{ Panel B: Diagnostic Tests } \\
\hline $\begin{array}{l}\text { Jarque-Bera } \\
\text { Stat. }\end{array}$ & $\begin{array}{c}3730.109^{* * *} \\
(0.000)\end{array}$ & $\begin{array}{c}1019.029^{* * *} \\
(0.000)\end{array}$ & $\begin{array}{c}335.123^{* * *} \\
(0.000)\end{array}$ & $\begin{array}{c}1949.999^{* * *} \\
(0.000)\end{array}$ & $\begin{array}{c}894.764^{* * *} \\
(0.000)\end{array}$ & $\begin{array}{c}730.445^{\star * *} \\
(0.000)\end{array}$ \\
\hline $\begin{array}{l}\text { Ljung-Box } \\
\text { Q-Stat (1) }\end{array}$ & $\begin{array}{c}9.6162^{\star * *} \\
(0.002)\end{array}$ & $\begin{array}{l}0.6515 \\
(0.420)\end{array}$ & $\begin{array}{l}0.3476 \\
(0.555)\end{array}$ & $\begin{array}{c}5.4986^{\star *} \\
(0.019)\end{array}$ & $\begin{array}{l}2.4609 \\
(0.117)\end{array}$ & $\begin{array}{c}5.1507^{* *} \\
(0.023)\end{array}$ \\
\hline $\begin{array}{l}\text { Ljung-Box } \\
\text { Q-Stat (5) }\end{array}$ & $\begin{array}{c}42.706^{* * *} \\
(0.000)\end{array}$ & $\begin{array}{l}9.0218 \\
(0.108)\end{array}$ & $\begin{array}{c}12.573^{* *} \\
(0.028)\end{array}$ & $\begin{array}{c}18.001^{\star * *} \\
(0.003)\end{array}$ & $\begin{array}{l}10.446^{*} \\
(0.064)\end{array}$ & $\begin{array}{c}0.036^{* * *} \\
(0.007)\end{array}$ \\
\hline $\begin{array}{l}\text { Ljung-Box } \\
\text { Q-Stat (10) }\end{array}$ & $\begin{array}{c}61.170^{\star * *} \\
(0.000)\end{array}$ & $\begin{array}{c}23.018^{* *} \\
(0.011)\end{array}$ & $\begin{array}{c}27.782^{\star * *} \\
(0.002)\end{array}$ & $\begin{array}{c}-0.001^{\star * *} \\
(0.001)\end{array}$ & $\begin{array}{l}11.918 \\
(0.291) \\
\end{array}$ & $\begin{array}{c}0.044^{\star * *} \\
(0.000)\end{array}$ \\
\hline \multicolumn{7}{|c|}{ Panel C: Correlations } \\
\hline DJIM & 0.3744 & & & & & \\
\hline DAX & 0.2754 & 0.8073 & & & & \\
\hline FTS & 0.2648 & 0.8186 & 0.8236 & & & \\
\hline NIK & 0.3134 & 0.5991 & 0.5190 & 0.5234 & & \\
\hline$S \& P$ & 0.3013 & 0.9254 & 0.7744 & 0.7784 & 0.4972 & \\
\hline
\end{tabular}

Notes: 1 . This table presents summary statistics of each index series. The data are weekly percentages, i.e., 100 times the log-differences of daily stock index returns. The sample period runs over 12 years from January 5th, 1997 to April 11th, 2009, yielding 640 observations in total. Panel A presents descriptive statistics. 2. Panel B reports test results. Under the null hypothesis of normality, the Jarque-Bera test statistics have a chi-square distribution with a fixed degree of 2 . The Ljung-Box Q-stat is the Ljung-Box statistics for serial correlation, corrected for heteroscedasticity, computed at 1,5 and 10 lags, respectively. The asterisks, $\left({ }^{*}\right)$, $(* *)$, and $\left(^{* *}\right)$ indicate a rejection of the null hypothesis at the $1 \%, 5 \%$, and $10 \%$ levels, respectively. P-values are reported in parentheses in Panel B. 3. Panel C reports the linear correlations between index returns. 
We find that, in Panel A of Table 1, the average return of ISE is lower than most of the major stock market indices except NIK with the Japanese stock market reporting the worst performance in recent times considering the negative average returns between 1997 and 2009. According to the standard deviations, the most volatile index is the DAX while the least volatile index is the FTS. The volatility of the ISE, measured by the standard deviation, is in the middle. All five major market indices, including the DJIM, exhibit negative skewness while the ISE shows positive skewness. All of these results indicate that the empirical distributions of weekly returns of the ISE and the five major market indices exhibit a non-normal pattern. We also find significant kurtosis in each series. ISE displays extremely high kurtosis indicating that more of the variance is due to infrequent extreme deviations.

In Panel B of Table 1, results of the Jarque-Bera (JB) test reject the null hypothesis of normality, indicating the non-normality of the unconditional distribution of each series. Ljung-Box autocorrelation test with correction for heteroskedesticity is implemented at lags 1, 5 and 10. It shows that most series are serially correlated except for DJIM and NIK. Finally, in Panel C of Table 1, the unconditional correlation matrix indicates that the correlations between DAX, FTS and S \& P are relatively higher than those between other pairs. Unconditional correlations between ISE and the four major market indices are lower than that between the ISE-DJIM pair. The linear unconditional correlation in ISE-related pairs ranges from 0.2648 to 0.3744 . The difference in the patterns of weekly returns of the ISE and the five major market indices is also evident from Figure 1.

We also examine the skewness and the kurtosis of returns together with the Lilliefors, Carmer-von Mises, Watson and Anderson-Darling normality test statistics. The distributional characteristics of the returns are presented in Table 2.

As expected, the returns are leptokurtic with all the normality tests rejecting the null hypothesis of Gaussian distributed returns. In such a situation, a single statistic such as beta estimated in the CAPM model is not able to correctly assess the dependency structure between the returns and the tail dependence may differ from dependence close to the mean. As mentioned earlier, the correlation coefficient estimated using CAPM is a scalar measure of dependency, and is unable to embody the required information about the dependence structure.

\subsection{CAPM and Copula Results}

Table 3 displays the CAPM regression results for the ISE against the DJIM and the four major Western indices. None of the five regressions report a significant alpha. This result again supports Shaw's [23] argument that the linear correlation coefficient cannot capture the non-linear dependence relationships that exist between many financial series. When evaluating systematic risk, we note that all the beta coefficients are significant at $1 \%$ level with the highest beta being 0.4009 (DJIM) and lowest beta being 0.2177 (DAX), implying that the funds in- 
cluded in the ISE are on average significantly less risky than the corresponding Islamic benchmark and the major Western benchmarks.

As a robustness check, we regress the excess returns of the DJIM (the Islamic benchmark) against the excess returns of the major Western indices. The results are reported in Table 4. Insignificant alphas are unable to inform if the Islamic benchmark outperforms the major Wester indices or not. All the beta coefficients are significant at $1 \%$ level. However, the highest beta reaches 0.9103 (SNP)
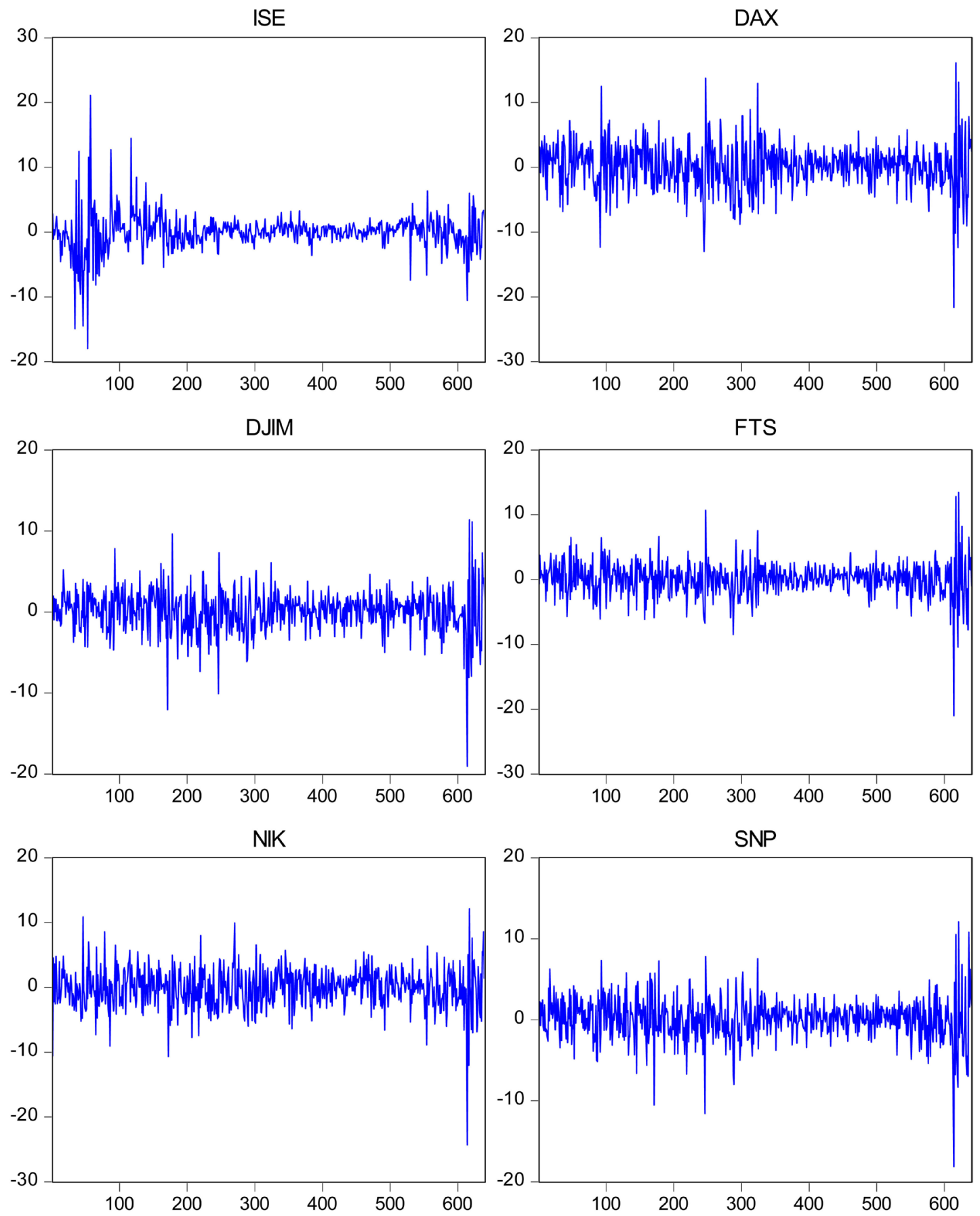

Figure 1. Weekly returns. 
Table 2. The normality test statistics of the returns.

\begin{tabular}{ccccc}
\hline Index & Lilliefors & Cramer-von Mises & Watson & Anderson-Darling \\
\hline ISE & 0.1232 & 3.9248 & 3.9181 & 21.9610 \\
DIM & 0.0540 & 0.8160 & 0.7784 & 4.9642 \\
SNP & 0.0650 & 0.8104 & 0.7984 & 5.0825 \\
FTS & 0.0593 & 0.8731 & 0.8533 & 5.6450 \\
DAX & 0.0505 & 0.5044 & 0.4865 & 3.2286 \\
NIK & 0.0382 & 0.2140 & 0.1962 & 1.7517 \\
\hline
\end{tabular}

Notes: This table reports the asymptotic test statistics for four normality tests. Lilliefors test statistic is employed instead of the Kolmogorov statistic since the parameters of the normal have been estimated.

Table 3. CAPM analysis (ISE).

\begin{tabular}{ccccc}
\hline & Alpha & Beta & Adj. R-sqr & Durbin-Watson Stat. \\
\hline \multirow{2}{*}{ DJIM } & -0.0227 & $0.4009^{* * *}$ & 0.1387 & 1.8214 \\
& $(0.8275)$ & $(0.0000)$ & & \\
DAX & -0.0165 & $0.2177^{* * *}$ & 0.0737 & 1.7986 \\
& $(0.8784)$ & $(0.0000)$ & & 1.7757 \\
FTS & -0.0130 & $0.2852^{\star * *}$ & 0.0688 & \\
& $(0.9044)$ & $(0.0000)$ & & 1.7705 \\
NIK & 0.0320 & $0.2779^{* * *}$ & 0.0955 & \\
& $(0.7641)$ & $(0.0000)$ & & 1.8057 \\
SNP & -0.0156 & $0.3172^{* * *}$ & 0.0891 & \\
& $(0.8839)$ & $(0.0000)$ & & \\
\hline
\end{tabular}

Notes: This table shows the CAPM regression results for the excess ISE returns against the excess returns of Dow Jones Islamic Market Index and the four major Western indices. The sample period runs over 12 years from January 5th, 1997 to April 11th, 2009, yielding 640 observations in total. The alpha and beta coefficients are equally weighted averages. The asterisks, $\left(^{*}\right),\left({ }^{*}\right)$, and $\left({ }^{* *}\right)$ indicate a rejection of the null hypothesis at the $1 \%, 5 \%$, and $10 \%$ levels, respectively. P-values are reported in parentheses.

Table 4. CAPM analysis (DJIM).

\begin{tabular}{ccccc}
\hline & Alpha & Beta & Adj. R-sqr & Durbin-Watson Stat. \\
\hline \multirow{2}{*}{ DAX } & 0.0082 & $0.5978^{* * *}$ & 0.6499 & 2.2525 \\
& $(0.8954)$ & $(0.0000)$ & & \\
FTS & 0.0144 & $0.8217^{* * *}$ & 0.6692 & 2.2436 \\
& $(0.8113)$ & $(0.0000)$ & & \\
NIK & 0.1226 & $0.4976^{* * *}$ & 0.3554 & \\
& $(0.1452)$ & $(0.0000)$ & & 2.2372 \\
SNP & 0.0071 & $0.9103^{* * *}$ & & \\
& $(0.8581)$ & $(0.0000)$ & 0.8558 & \\
\hline
\end{tabular}

Notes: This table shows the CAPM regression results for the excess DJIM returns against the excess returns of the four major Western indices. The sample period runs over 12 years from January 5th, 1997 to April 11th, 2009, yielding 640 observations in total. The alpha and beta coefficients are equally weighted averages. The asterisks, $\left({ }^{*}\right),\left({ }^{*}\right)$, and $\left({ }^{* *}\right)$ indicate a rejection of the null hypothesis at the $1 \%, 5 \%$, and $10 \%$ levels, respectively. P-values are reported in parentheses. 
and the adjusted R-squared statistics are much higher than those in Table 3. This result implies that the Islamic Equity Funds provide good diversification benefits to the investors, even when compared to the Islamic market index.

The time path of dependence parameters are presented in Figure 2 to Figure 6. We report the Gaussian Copula parameter estimates for both constant and time-varying cases of all five pairs1; ISE/DJIM, ISE/DAX, ISE/FTS, ISE/NIK, and ISE/SNP, as well as, the rotated Gumbel Copula and SJC Copula lower-tail and upper-tail parameter estimates as robustness checks.

Note that most of the time paths seem informative. For example, in Figure 2, for the ISE/SNP pair the dependence is quite volatile over time and it ranges between $0.30-0.40$ prior to 2007. The time-varying dependence reaches a high of 0.55 during the GFC. This pattern is also evident for the other four pairs. We also find that for all five pairs, SJC Copula lower-tail dependence is slightly higher than the upper-tail dependence. Hence there is a higher probability of joint extreme events (EVT) during the bear market than during the bull market. The rotated Gumbel Copula time-varying dependence parameters also support a statistically significant dependence change before and during the GFC. Our results confirm the findings of Smolo and Mirakhor [36] [37] that the GFC had limited impact on the Islamic financial industry.

\section{Concluding Remarks}

Dependence structure is an important issue in understanding the individual financial asset's return against a market benchmark. Linear measures, such as alpha and beta estimated by the traditional CAPM model and the Carhart model, provide an easy and convenient way to describe the performance and co-movement of Islamic funds. However, they are not the appropriate dependence measures and may be highly biased in certain non-normal situations.

In this study, we use both the traditional CAPM model and the time-varying conditional Copula models to study the co-movement and dependence structures between the Europe Open-end Islamic Shari ah Equity index and the Dow Jones Islamic Market index and the four major Western stock market indices for the period between 1997 and 2009. Three different Copulas are considered: Normal Copula with general dependence, SJC Copula with upper and lower tail dependence, and Rotated Gumbel Copula. The following can be implied from our results:

First, the results of four normality tests show that the returns of the Europe Open-end Islamic Shariah Equity index and the five major stock indices are leptokurtic. All normality tests reject the null hypothesis of Gaussian distributed returns. On such occasions, a single statistic such as beta estimated in the CAPM model is not able to correctly assess the dependency structure between the returns.

Second, CAPM regressions are not able to provide significant alpha estimations. All beta coefficients are significant at $1 \%$ level, and the highest beta is 0.4009 (DJIM) and lowest beta is 0.2177 (DAX), which implies that the funds 

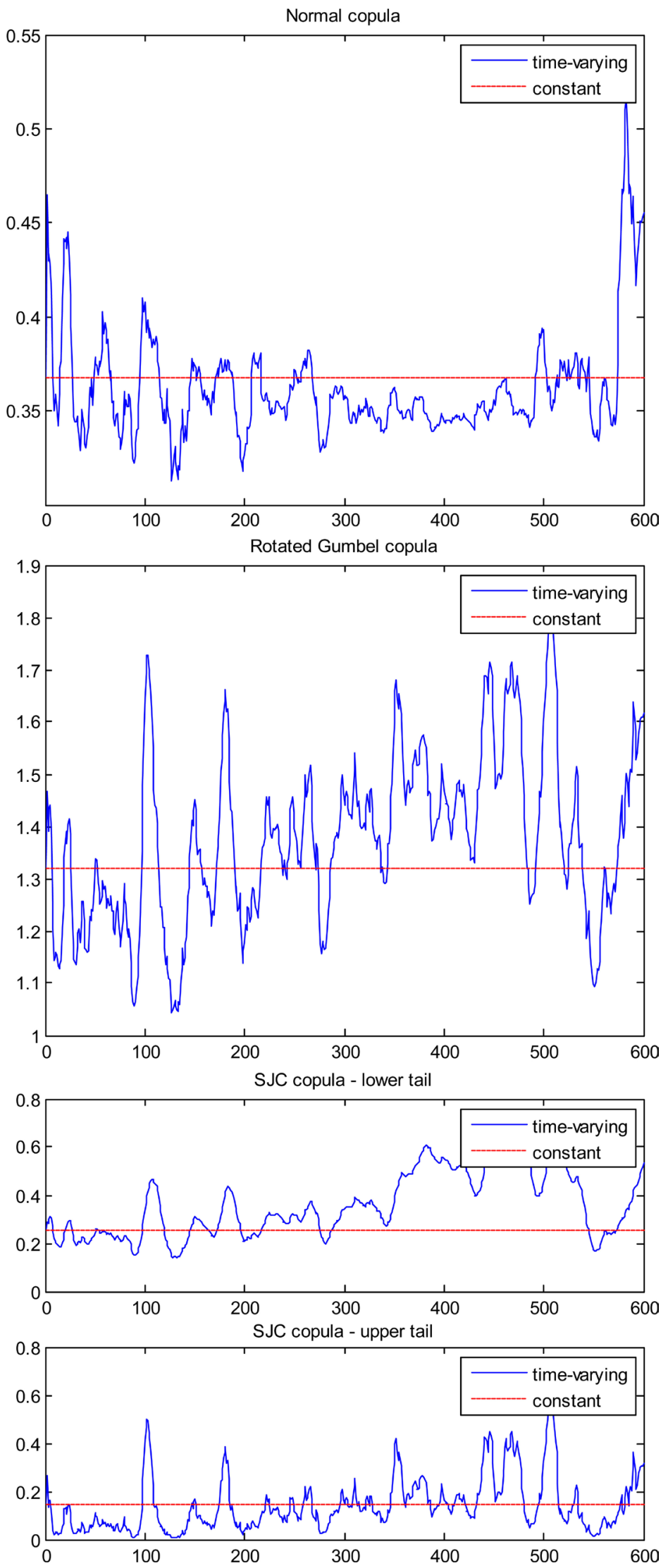

Figure 2. Time path of dependence parameters for ISE/SNP. 

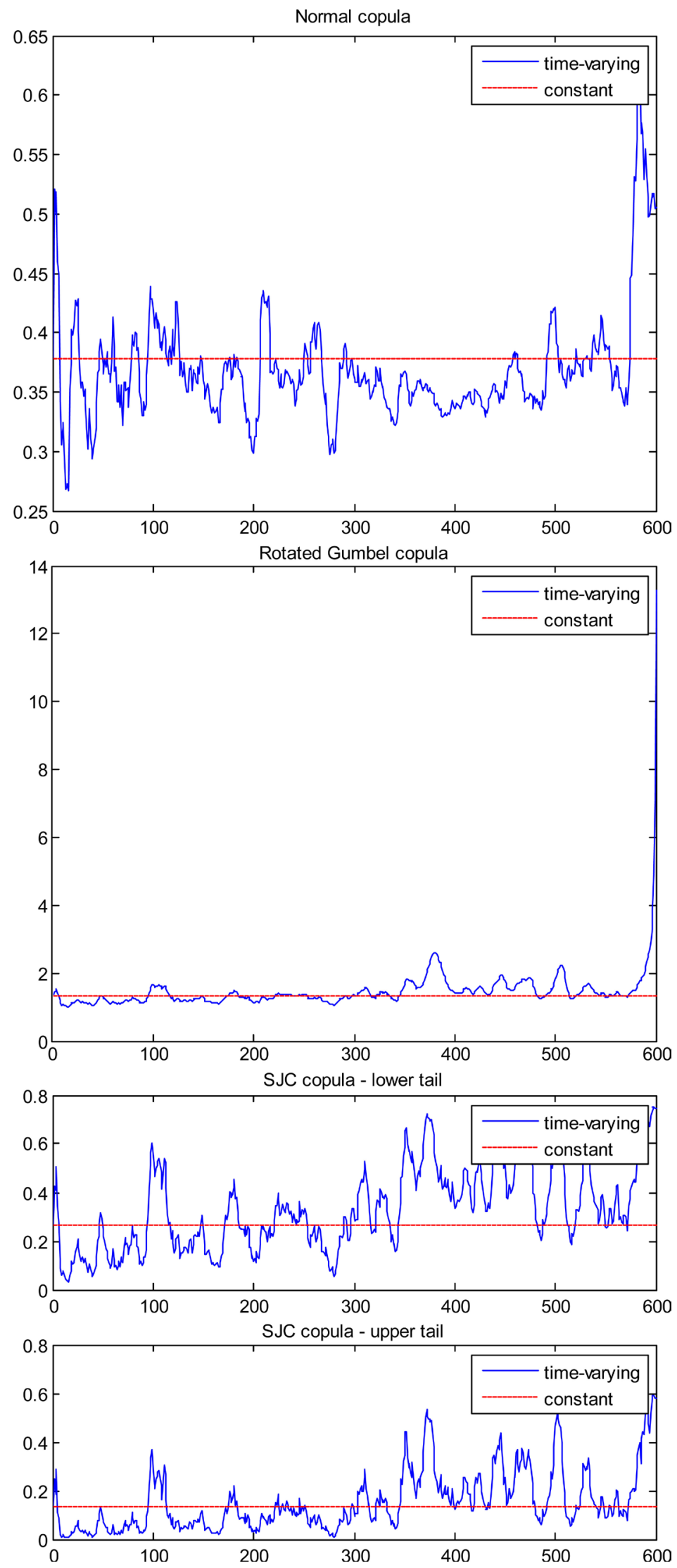

Figure 3. Time path of dependence parameters for ISE/DAX. 

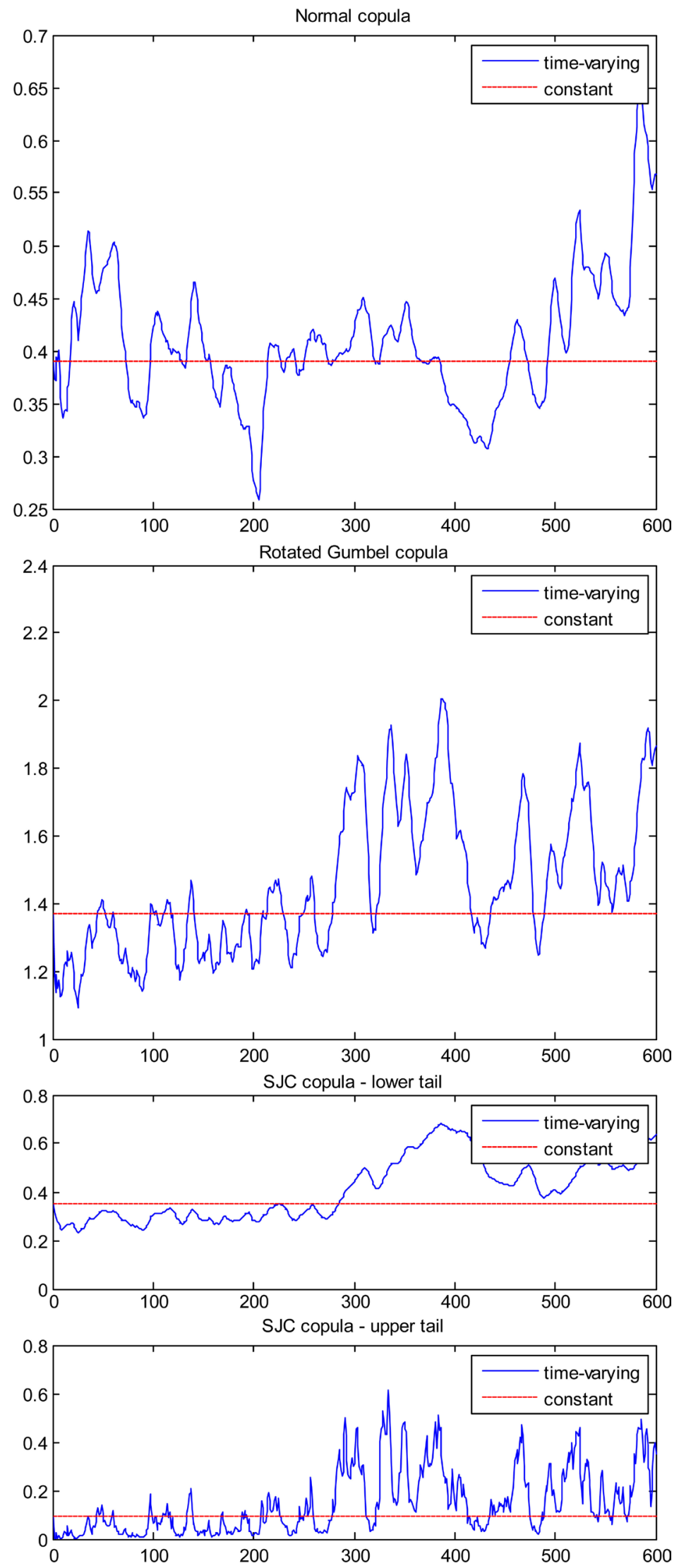

Figure 4. Time path of dependence parameters for ISE/NIK. 

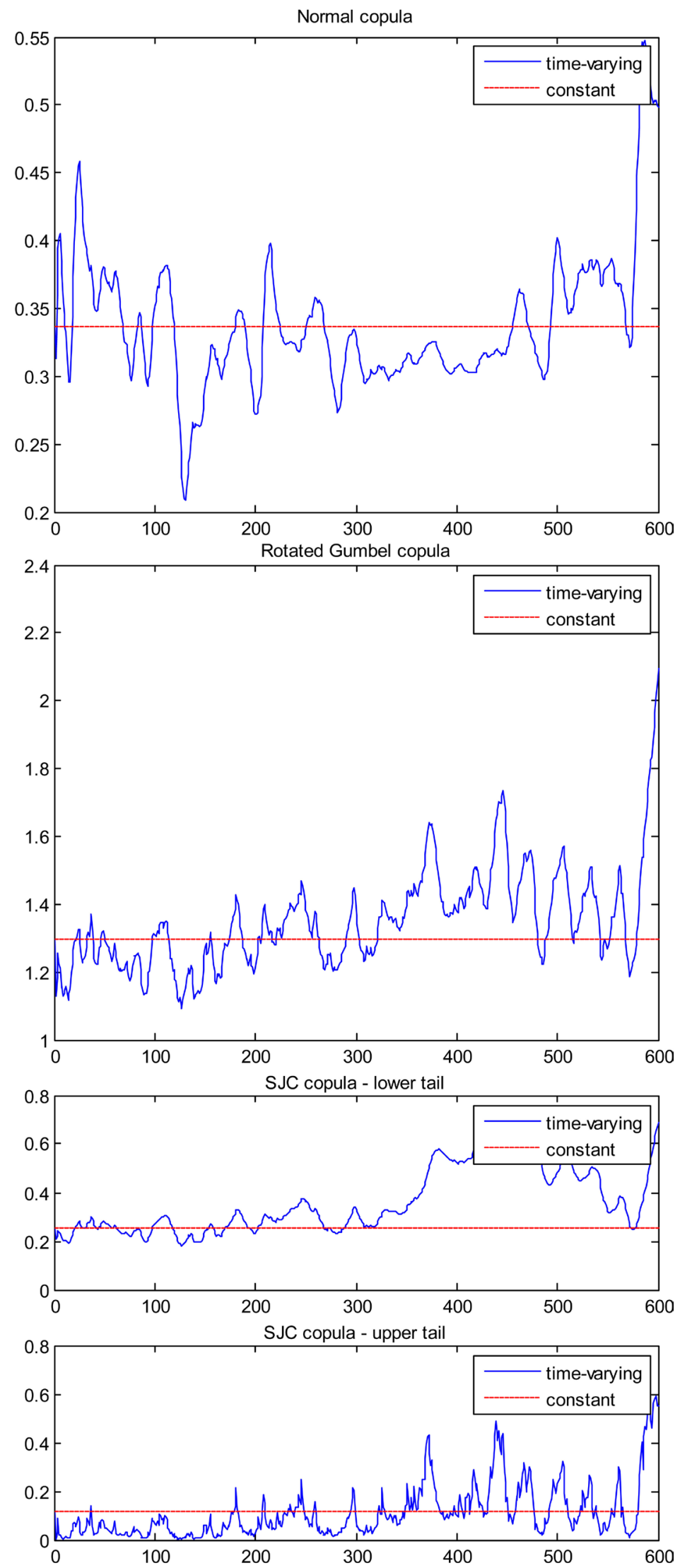

Figure 5. Time path of dependence parameters for ISE/FTS. 

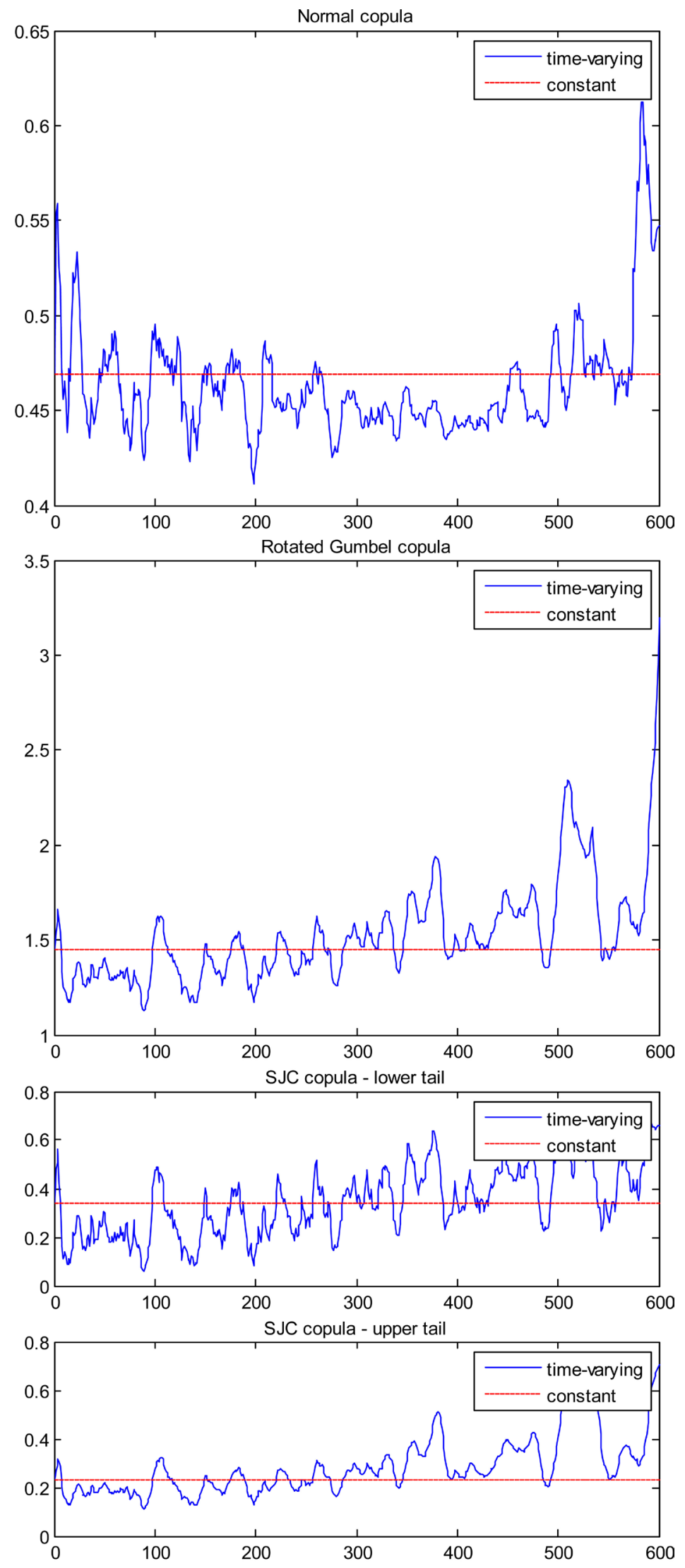

Figure 6. Time path of dependence parameters for ISE/DJIM. 
included in Europe Open-end Islamic Shari ah Equity index are on average significantly less risky than the corresponding Islamic benchmark and the major Western benchmarks. This result implies that the Islamic Equity Funds provide relatively better diversification benefits to the investors, even in comparison with the Islamic market index.

Third, normal Copula parameter estimates suggest that the Islamic investment funds have low dependence with the major Western market indices before the GFC. The fluctuation in the financial markets in the U.S., U.K., Germany and Japan is less likely to affect the Islamic investment funds relative to other financial assets. One of the implications is that Islamic investment funds are not only attractive for Muslim investors, but also a good alternative for the fund managers to diversify their portfolios.

Last, the time-varying dependence between Islamic Shari ah Equity index and Dow Jones Islamic Market index and the four major Western market indices increases dramatically during the GFC. This finding is supported by the SJC Copula results. SJC Copula lower-tail dependence is slightly higher than the upper-tail dependence indicating that there is a higher probability of joint extreme events during the bear market than during the bull market. The implication here is that diversification benefits of including the Islamic equity funds in the portfolio seem to deteriorate in the financial crisis.

\section{Acknowledgements}

We are thankful to the editor, 2 anonymous referees, Geoff Booth and Gary Magee for the constructive comments on an earlier version of this paper. Initial version of the paper was presented at the Adam Smith Business School conference on Islamic accounting and Finance, University of Glasgow. Comments from the participants are acknowledged. However, all the errors remain the responsibility of the authors.

\section{Conflicts of Interest}

The authors declare no conflicts of interest regarding the publication of this paper.

\section{References}

[1] Mansor, F., Bhatti, M.I. and Ariff, M. (2015) New Evidence on the Impact of Fees on Mutual Fund Performance of Two Types of Funds. Journal of International Financial Markets, Institutions and Money, 35, 102-115.

https://doi.org/10.1016/j.intfin.2014.12.009

[2] Vige Rating (2015). http://www.vigeo.com/csr-rating-agency/attachments/article/168/Green\%20Social\% 20And\%20Ethical\%20Funds\%20In\%20Europe\%202015.pdf

[3] Zeti, A.A. (2012) Islamic Financial Works in Fostering Sustainable Economic Growth. The Jakarta Post, 21 December 2012.

[4] Khan, M.M. and Bhatti, M.I. (2008) Development in Islamic Banking: A Financial 
Risk-Allocation Approach. The Journal of Risk Finance, 9, 40-51. https://doi.org/10.1108/15265940810842401

[5] Mansour, W. and Bhatti, M.I. (2018) The New Paradigm of Islamic Corporate Governance. Managerial Finance, 44, 513-523.

https://doi.org/10.1108/MF-01-2018-0043

[6] Failaka Islamic Funds Database, 2009. http://www.failaka.com/customer/fundSearch.htm

[7] Wilson, R. (2004) Screening Criteria for Islamic Equity Funds. In: Jaffer, S., Ed., Islamic Asset Management. Forming the Future for Shari ah-Compliant Investment Strategies, Euromoney Books, London, 35-45.

[8] Hayat, R. and Kraeussl, R. (2011) Risk and Return Characteristics of Islamic Equity Funds. Emerging Markets Review, 12, 189-203. https://doi.org/10.1016/j.ememar.2011.02.002

[9] Basov, S. and Bhatti, M.I. (2013) Optimal Contracting Model in a Social Environment and Trust-Related Psychological Costs. B.E. Journal of Theoretical Economics, 13, 271-284. https://doi.org/10.1515/bejte-2012-0011

[10] Basov, S. and Bhatti, M.I. (2014) On Shari'ah Compliance, Positive Assortative Matching, and Return to Investment Banking. Journal of International Financial Markets, Institutions and Money, 30, 191-195. https://doi.org/10.1016/j.intfin.2013.12.010

[11] Wahla, E., Hasan, A. and Bhatti, M.I. (2018) Measures of Customers' Perception of Car Ijarah Financing. Journal of Islamic Accounting and Business Research, 9, 2-16. https://doi.org/10.1108/JIABR-10-2015-0051

[12] Derigs, U. and Marzban, S. (2009) New Strategies and a New Paradigm for Shari'ah-Compliant Portfolio Optimization. Journal of Banking and Finance, 33, 1166-1176. https://doi.org/10.1016/j.jbankfin.2008.12.011

[13] Choudhury, M.A. and Bhatti, M.I. (2016) Heterodox Islamic Economics. Routledge, Abingdon-on-Thames.

[14] Basov, S. and Bhatti, M.I. (2016) Islamic Finance in the Light of Modern Economic Theory. Palgrave MacMillan, Basingstoke. https://doi.org/10.1057/978-1-137-28662-8

[15] Chong, B.S. and Liu, M.H. (2009) Islamic Banking: Interest-Free or Interest-Based? Pacific-Basin Finance Journal, 17, 125-144. https://doi.org/10.1016/j.pacfin.2007.12.003

[16] Abdullah, F., Mohamed, S. and Hassan, T. (2007) Investigation of Performance of Malaysian Islamic Unit Fund Trusts, Comparison with Conventional Unit Fund Trusts. Managerial Finance, 33, 142-153. https://doi.org/10.1108/03074350710715854

[17] Mansor, F. and Bhatti, M.I. (2014) Timing and Investment Performance of Islamic Mutual Funds: A Panel Data Analysis. Science International, 26, 2385-2393.

[18] Hoepner, A.G.F., Rammal, H.G. and Rezec, M. (2011) Islamic Mutual Funds' Financial Performance and International Investment Style: Evidence from 20 Countries. The European Journal of Finance, 17, 829-850. https://doi.org/10.1080/1351847X.2010.538521

[19] Cont, R. (2001) Empirical Properties of Asset Returns: Stylized Facts and Statistical Issues. Quantitative Finance, 1, 223-236. https://doi.org/10.1080/713665670

[20] Bhatti, M.I. and Nguyen, C. (2012) Diversification Evidence from International Equity Markets Using Extreme Values and Stochastic Copulas. Journal of Internation- 
al Financial Markets, Institutions and Money, 22, 622-646. https://doi.org/10.1016/j.intfin.2012.02.004

[21] Nguyen, C., Bhatti, M.I. and Hayat, A. (2014) Volatility Linkages in the Spot and Futures Market in Australia: A Copula Approach. Quality and Quantity, 48, 2589-2603. https://doi.org/10.1007/s11135-013-9909-2

[22] Nguyen, C., Bhatti, M.I., Komornikova, M. and Komornik, J. (2016) Gold Price and Stock Markets Nexus under Mixed-Copulas. Economic Modelling, 58, 283-292. https://doi.org/10.1016/j.econmod.2016.05.024

[23] Shaw, J. (1997) Beyond VaR and Stress Testing. In: Grayling, S., Ed., VaR: Understanding and Applying Value at Risk, Risk Publications, London, 211-224.

[24] Belkacem, L., Vehel, J. and Walter, C. (2000) CAPM, Risk and Portfolio Selection in $\alpha$-Stable Markets. Fractals, 8, 99-115. https://doi.org/10.1142/S0218348X00000111

[25] Longin, F. and Solnik, B. (2001) Extreme Correlation of International Equity Markets. Journal of Finance, 56, 649-676. https://doi.org/10.1111/0022-1082.00340

[26] Ang, A. and Chen, J. (2002) Asymmetric Correlations of Equity Portfolios. Journal of Financial Economics, 63, 443-494. https://doi.org/10.1016/S0304-405X(02)00068-5

[27] Patton, A.J. (2006) Modelling Asymmetric Exchange Rate Dependence. International Economics Review, 47, 527-556. https://doi.org/10.1111/j.1468-2354.2006.00387.x

[28] Rodriguez, J. (2007) Measuring Financial Contagion: A Copula Approach. Journal of Empirical Finance, 14, 401-423. https://doi.org/10.1016/j.jempfin.2006.07.002

[29] Ahsanullah, M. and Bhatti, M.I. (2010) On Dependence Functions of Copulas of Gumbel's Bivariate Extreme Value and Exponential Distributions. Journal of Statistical Theory and Applications, 9, 615-629.

[30] Usmani, M.T. (2005) Salam and Istisna. http://www.accountancy.com.pk

[31] Nisar, S. and Khatkhatay, M.H. (2006) Shari'ah-Compliant Equity Investment: An Assessment of Current Screening Norms. In: Proceedings of the Fourth Harvard University Forum on Islamic Finance, Harvard University, Cambridge.

[32] Morningstar, 2009.

http://www.morningstar.co.uk/uk/fundquickrank/default.aspx?lang=en-GB\&catego ry=EUCA000673

[33] The Hedge Fund Journal, 2009.

http://www.thehedgefundjournal.com/news/2009/01/09/dubai-launches-new-Shari' ah-hedge-fund-index.php

[34] Nelsen, R.B. (2006) An Introduction to Copulas. 2nd Edition, Springer, New York.

[35] Joe, H. (1997) Multivariate Models and Dependence Concepts. Chapman \& Hall, London. https://doi.org/10.1201/b13150

[36] Smolo, E. and Mirakhor, A. (2010) The GFC and Its Implications for the Islamic Financial Industry. International Journal of Islamic and Middle Eastern Finance and Management, 3, 372-385. https://doi.org/10.1108/17538391011093306

[37] Al Rahahleh, N., Bhatti, M.I. and Misman, F. (2019) Developments in Risk Management in Islamic Finance: A Review. Journal of Risk and Financial Management, 12, 1-22. 